\title{
Problems in Defining Ethnicity Terms in Dictionaries
}

\author{
Dragica Žugić, Faculty of Philology, University of Donja Gorica, Podgorica, \\ Montenegro (dragica.zugic@udg.edu.me) \\ and \\ Milica Vuković-Stamatović, Faculty of Philology, University of Montenegro, \\ Nikšić, Montenegro (vmilica@ucg.ac.me)
}

\begin{abstract}
Despite the fact that lexicographers have increasingly been taking more care when it comes to defining socially sensitive terms, we argue that ethnicity terms still remain rather poorly defined. In a number of online monolingual dictionaries we surveyed in this study, we find that ethnicity terms are generally simplistically defined, mostly in terms of geography and citizenship, and argue that such definitions are too reductionist and sometimes even erroneous. We also find that some disparaging ethnicity terms are not labelled as such in some of the dictionaries surveyed. We also present a case study from Montenegro, in which a dictionary of the national academy of sciences was immediately revoked over a few ethnicity and ethnicity-related terms, after a violent outcry from two of Montenegro's ethnic minorities, dissatisfied with how their ethnicities were defined and treated in the dictionary. Based on our survey and the earlier findings from the literature, we recommend that international dictionaries follow a standardised model of defining ethnicities, which would additionally refer to an ethnicity's culture and potentially language, and be as inclusive as possible. We also recommend that editors and lexicographers of national dictionaries pay special attention to how they define the ethnic terms relating to the minorities living in their country or region, following a combination of a standardised and a partly customised approach, which would take into account the specific features of the minorities.
\end{abstract}

\section{Keywords: ETHNICITY TERMS, ETHNICITY-RELATED TERMS, DICTIONARIES, LABELS}

Opsomming: Probleme met die definiëring van etniese terme in woordeboeke. Ondanks die feit dat leksikograwe in die definiëring van sosiaal-sensitiewe terme toenemend versigtigheid aan die dag lê, word hier aangevoer dat etniese terme steeds redelik swak gedefinieer is. In ' $n$ aantal aanlyn eentalige woordeboeke wat ons in hierdie studie ondersoek het, vind ons dat etniese terme oor die algemeen simplisties gedefinieer word, meestal in terme van geografie en burgerskap, en ons redeneer dat hierdie definisies té reduksionisties en soms selfs foutief is. Dit het ook geblyk dat sommige neerhalende etniese terme in sommige van die woordeboeke wat ondersoek is nie as sodanig geëttiketteer is nie. Ons lê ook 'n gevallestudie uit Montenegro voor, waarin 'n woordeboek van die nasionale akademie van wetenskappe weens 'n paar etniese en etniesverwante terme onmiddellik onttrek is ná die geweldadige protes van twee etniese minderhede in Montenegro wat ontevrede was met die manier waarop hul etnisiteite in die woordeboek gedefinieer en hanteer is. Gegrond op ons ondersoek en die vroeëre bevindings uit die literatuur, stel ons voor dat internasionale woordeboeke ' $n$ gestandaardiseerde model vir die definiëring van etniese terme volg wat ook sal verwys na die kultuur en moontlik taal van 'n etniese groep, en wat

Lexikos 31 (AFRILEX-reeks/series 31: 2021): 177-194 
so inklusief moontlik sal wees. Ons beveel ook aan dat redakteurs en leksikograwe van nasionale woordeboeke besondere aandag skenk aan die manier waarop hulle die etniese terme rakende minderhede wat in hul land of streek woon, definieer deur 'n kombinasie van 'n gestandaardiseerde en gedeeltelik pasgemaakte benadering te volg waarin die spesifieke eienskappe van die minderhede in ag geneem sal word.

Sleutelwoorde: ETNIESE TERME, ETNIESVERWANTE TERME, WOORDEBOEKE, ETIKETTE

\section{Introduction}

A typical user expects a general dictionary to contain ethnicity terms and to define them (Rader 1989). However, even though lexicographers have been making great efforts to improve their treatment of various politically sensitive and socially charged terms over the last decades, ethnic terms in dictionaries are still described rather poorly, usually just in geographical terms and even in those cases, sometimes too restrictively. To some ethnic groups such definitions may be offensive and a dictionary can face a strong public backlash on account of this. In this paper we will describe one such recent case from Montenegro, as well as inspect the literature on the issue and comparatively analyse the definitions of ethnic terms in various online monolingual dictionaries (English, German, Italian, Croatian, Serbian, and Albanian).

We start the paper by surveying the relevant literature on how dictionaries treat politically sensitive terms, with a special focus on ethnic terms.

\section{Treatment of politically sensitive terms in dictionaries}

The present paper follows the tradition of studying how dictionaries treat politically sensitive terms. Some of the studies exploring these issues include the following: the treatment of ethnic names (Rader 1989), racial terms (Murphy 1991, 1998) and political terms (Dieckmann 1975; Veisbergs 2002); ideological aspects of dictionaries in general (Moon 1989; Ezquerra 1995; Wierzbicka 1995); use of offensive language (Schutz 2002); the issue of political correctness, with special emphasis on the treatment of gender (Barnickel 1999), etc. As can be seen, these studies overlap somewhat in their topics of interest and how they approach them; for our present purposes, we will say that the present paper deals with how ethnic names or ethnonyms, as politically and socially charged terms, are dealt with in dictionaries.

As Murphy (1998) argues, this type of research is conducted with two purposes in mind. The first refers to highlighting the inaccuracies and prejudice in dictionaries so that they can be corrected in later editions and prevented from occurring in new dictionaries. Insensitive treatment of some terms (particularly racial and ethnic, Murphy notes) may provoke a public outcry, as well 
as organised boycotts, protests and even the banning of a dictionary (see Subsection 2.2). One such recent case will be described later in the paper (Section 4). The second purpose of this type of research is to make a contribution to how we understand the relations between language, on the one hand, and social attitudes and categorisations, on the other.

All the studies mentioned reveal that dictionary definitions are indeed sometimes insensitive or ideologically charged. Reflecting the nature of human beings, the vocabulary of every language contains "unpleasant" language. Therefore, naturally, the lexicon itself will reflect unpleasant stereotypes (Schutz 2002: 640). All authors agree that ideologies, political and social aspects will always be present in the definitions and that ideologically neutral entries as a whole cannot exist (cf. Moon 1989; Ezquerra 1995; Schutz 2002). Veisbergs (2002) notes that even some seemingly innocuous choices, such as the choice of a spelling variant, for instance, may reflect ideology - e.g. by our subscribing to British spelling in this paper we take a position and reject the American one. Some of the other choices we make may be seen as offensive by some groups and the same definitions may be seen quite differently by different ideological groups.

Items in dictionaries may be offensive in two ways, Schutz (2002) finds either directly, i.e. those used offensively with a deliberate intention, typically name-calling (e.g. nigger for a black person) or indirectly, which is far more often the case. For instance, in the examples accompanying the entry for the noun research in the online Cambridge English Dictionary 1 , we found an overuse of the pronoun he vs. she. Namely, in the 7 examples accompanying the definition of the term, three contained a third person singular personal pronoun and all with a male referent (e.g. his researches ...; he dedicated his life to science; he emphasised ...). While modern dictionaries are making great efforts to avoid such infelicities, they unavoidably still do happen. This is due to the fact that many modern dictionaries are based on authentic corpora and authentic corpora reflect reality, which, in this case, includes the reality that some occupations are stereotypically seen as predominantly male jobs (typically those requiring physical strength, but also some highly intellectual ones, such as being a researcher). In addition, corpora themselves are composed of texts which are censored (every text, prior to its publication, undergoes some sort of censorship, at least self-censorship), which means that the word list based on such a corpus may not contain some words which are politically undesirable (Wierzbicka 1995: 194).

Another issue frequently cited as leading to bias in dictionaries is the fact that lexicographers are just humans and thus have human weaknesses, such as their debts to other people and their attachment to certain ideas (Ezquerra 1995: 151). They are also very likely to be imbued with their own culture, which shapes their understanding and perceptions (Veisbergs 2002). This all, of course, applies to the editor(s) of a dictionary as well. Landau (1984: 303) ${ }^{2}$ finds that dictionaries reflect prejudice and views of the upper classes, those established and well-educated ones, and so present what is valued by such groups. Dic- 
tionaries thus often reflect the leading social ideologies (Kalogjera 2001: 263).

Context is also very important in the study of potentially insulting words. Murphy (1991: 21) notes that "much of the usage labelling of racial, sexual and other epithets is based on the assumption that a member of the outgroup is using the term to describe the given ingroup". And while nigger may be used by the ingroup members to refer to themselves, it is certainly derogatory when used by the outgroup.

These issues especially become visible in the dictionaries produced under totalitarian regimes. Veisbergs (2002) observes that, inter alia, in such dictionaries some words are typically banned, while others, usually the politically charged ones, are purposefully misrepresented; in addition, some political terms are given plenty of dictionary space whereas some easily undergo a U-turn revision after certain ideas are rehabilitated in the society concerned.

These are, of course, extreme cases of visible bias in a dictionary; however, the dictionaries produced in modern democratic societies also feature some ideological distortions, in a much milder form, such as the gender bias discussed above. In the modern world, there is a growing need to correct such issues in language in general and, consequently, in dictionaries. Much of this has been driven by the movement advocating political correctness, which started in the '70s (Barnickel 1999). Some of the corrections made in the English dictionaries on account of greater sensitivities include a different treatment of the compound occupational names containing a "man"-element, e.g. the dictionaries now tend to add an admonitory note to terms for occupations ending in -man (e.g. salesman, policeman ...). The examples accompanying definitions in the dictionaries are now carefully chosen to avoid ones reflecting stereotypes; and, increasingly, care is taken to use neutral pronouns such as I or they or everyone, etc. instead of he and she; etc. (Barnickel 1999). The requests made in the name of political correctness have also been criticised as unduly exaggerated in some cases (which is why the term has itself deteriorated and now it might even have a negative ring to many), whereas the very concept is somewhat controversial and contended by those opposing any type of censorship (Busse 2000).

\subsection{Treatment of ethnic terms in dictionaries}

Before we delve into the research done on ethnic terms or ethnonyms, we will define what mean under the term "ethnicity". This complex term has received many different definitions in various social sciences, but most of them present it very broadly in scope and do not clearly distinguish between "ethnicity" and other close terms, such as "race" and "nationality". For Horowitz (1985) and many authors who follow his classification, ethnicity is, in fact, an umbrella term for these concepts (Chandra 2006). Similarly, some authors, including Francis (1947), Rothschild (1981), Connor (1984) and Brass (1991), do not systematically distinguish between an ethnic group and a nation, and find the two largely synonymous (Gabbert 2006). For them, an ethnicity may refer to a 
minority in a state, e.g. French Canadians in Canada, as well as to the French in France (Gabbert 2006). We will adhere to such an understanding of the term ethnicity, covering both these situations. In this paper, the term ethnicity was chosen rather than the term nationality for two reasons, cited in $\mathrm{Xu}$ (2002): first, while ethnicity is more of an academic concept, nationality is rather a legal and/or political one; second, ethnicity as a term can be more widely used than the term nationality, i.e. ethnicity can be a synonym for nationality, while the converse is not always the case. Thus, under such a broad definition, all the examples cited in this paper are considered as ethnicity labels.

The research on ethnicity terms can be divided into two strands - on the one hand, many studies have dealt with how the insulting nature of some ethnicity words is labelled in dictionaries and, on the other, little research has been conducted into the definitions of the ethnic terms which are generally not offensive.

Busse (2000), for instance, studies the insulting abbreviations for ethnicities (Frog, Jap, Kraut ...) in some English learners' dictionaries and argues that, even though these terms are racist, students need to know their connotations when encountering them and advises on including them in the dictionaries. The dictionaries Busse studied varied on whether and how many of these terms they included, as well as what labels were used for indicating the genre range in which the terms are used - some were marked as taboo and some as informal (which suggests less insulting connotations than taboo). Busse commends the fact that the Oxford Advanced Learner's Dictionary puts a ! sign next such terms, as an indication to a foreign learner that these words should be avoided in use.

In the same vein of research, Norri (2000) and Nissinen (2015) find that learners' dictionaries typically have more warnings for potentially insulting words, whereas slang dictionaries (Nissinen 2015) tend to use them the least. On the other hand, some dictionaries simply decide to omit such entries (Norri 2000). In this strand of research we also find a study conducted by Ştefănescu (2015) on labelling disparaging ethnicity words in Romanian dictionaries and Wachal's (2000) study of labelling of taboo words in British and American dictionaries.

When it comes to defining ethnicity terms that themselves have no such obvious insulting connotations, fewer studies are available. Rader (1989) argues that ethnic terms should be defined in dictionaries. Despite the typical derivational and etymological connection which exists between an ethnonym and a certain place-name, geographical criteria should not be the sole criteria in such definitions, he argues. He specifically mentions the problem of an "over- or underlap between ethnic group and citizenship", typically ignored in the dictionaries. As an example, he gives the term Hungarian, usually defined as "a native/ inhabitant of Hungary", even though there are other ethnicities living in Hungary (Serbs and Slovaks, among others) as well as significant communities of ethnic Hungarians living in other countries (Romania, Serbia, The Czech Repub- 
lic, Slovakia, etc.). Rader (1989: 133) states that "in some instances ethnicity should be separated from citizenship, and each accorded a separate definition, though I hesitate as to where the line should be drawn".

In one part of her paper, Murphy (1998) deals with the ethnicity terms in South African English dictionaries. She notes that complex issues were sometimes oversimplified in the dictionaries, which she thinks may well be acceptable for an international audience, who just needs to have a general idea of some terms, but not acceptable for the members of those ethnicities, who want a more technical or specific definition of an ethnic term that they already know (cf. Murphy 1998: 13). Therefore, the dictionary's target audience needs to be taken into account when defining these terms and certainly much more is expected of a general-purpose dictionary which is to be used locally than of a dictionary intended for an international audience, especially a learners' dictionary. Also, if certain ethnicity and ethnicity-related terms are particularly sensitive in some societies, these considerations need to be taken into account.

Rader (1989) and Murphy (1998) both find that most of the definitions of ethnic terms in dictionaries are rather simplistic, being typically geographically based, although "this common failing has been criticised for over a century" (Rader 1989: 21). In her corpus, Murphy found just one dictionary attempting to go beyond a geographical definition, but this resulted in some problematic cultural stereotypes appearing in the work. Both Rader (1989) and Murphy (1998) find that some level of standardisation of ethnicity definitions in dictionaries is certainly necessary.

Despite claims of descriptiveness, dictionaries can have a prescriptive effect (Busse 2000: 166). Bearing in mind the authoritative role they have in the modern society, both in terms of perception and education (Veisbergs 2002) and even the legal role they play in some countries given that their definitions are used in court cases (Moon 1989), every effort should be taken to address the issues raised by the studies referred to above. Research has shown that modern dictionaries have greatly improved in this respect but that there still remains room for improvement, which is why these type of studies are very important.

\subsection{Public reaction to the treatment of ethnic terms in dictionaries}

Hauptfleisch (1993: 84-85) states that there are two possible directions in which a public may react to how some ethnic terms are treated in a dictionary. On the one hand, he explains that critical comments coming from individual users and reviewers are quite common and should not be "unduly worrying" as they may help improve the dictionary in its ensuing editions. On the other hand, a more serious threat, one which may affect not only the dictionary itself but also the lexicographer, in terms of his/her self-confidence and status, comes from pressure groups in a community. This may take the form of an organised protest against the definitions and labelling of some derogatory terms, and also against the very inclusion of some lexical items that have offensive connotations. 
Hauptfleisch (1993) further gives a brief history of such public outcries. An often-cited essay is that of Burchfield (1980), who had edited the Oxford English Dictionary for thirty years, about his experiences following the publication of the definitions of some senses of the ethnic terms such as Jew, Palestinian and Pakistani in the Concise Oxford Dictionary. The pressure included boycotts of the dictionary and confiscations of its copies, until the contested definitions were amended. Even legal action was taken but the plaintiff lost the case. From such experiences, editors may learn that they need to devote maximum attention to sensitive terms, Burchfield (1980: 292) concludes and argues that dictionaries may aim to be normative only by the use of cautionary labels and/or symbols.

A judge also ruled in the favour of the publisher of the Van Dale dictionary, which included some negative expressions regarding Jews, as reported by Hauptfleisch (1993). As Burchfield, he also concludes that such situations make editors more aware of the sensitivity of some terms and more cautious in how they handle them, which is a positive thing. Still, Hauptfleisch advises against succumbing under pressure and keeping a cool head in adhering to professional standards in a dispassionate way.

\section{Ethnicity terms in various dictionaries}

For the purposes of this paper, we inspected various online monolingual dictionaries and how they define ethnicities. We explore this issue using one specific ethnicity term only, but the findings are generalisable. We specifically sought entries for the ethnicity term Albanian as the definition for this entry proved to be contentious in the Montenegrin case study, which will be presented in section 4 . We excluded the sense "Albanian language".

We used monolingual dictionaries which are freely accessible online, under the assumption that most users will first resort to these in an effort to look up an ethnicity term. As a result, different dictionaries are included in our study - most of them are general-purpose dictionaries, but there are also some learners' dictionaries. We covered dictionaries for several languages - English, as expected, had the largest number of free online monolingual dictionaries. We also inspected monolingual online dictionaries of German, Italian, Croatian, and Serbian, as these countries, amongst others, have considerable Albanian communities living in them. The number of the online monolingual dictionaries varied, depending on the language in question. We also included the Albanian free online monolingual dictionaries in the overview.

In the table below, we provide an overview of the dictionaries used and how they define the entry Albanian - both nouns and adjectives were inspected. Links to the relevant definitions of the entry Albanian, are given in the footnotes. The definitions from non-English dictionaries were literally translated into English. 


\begin{tabular}{|c|c|}
\hline Dictionary & Definition of Albanian \\
\hline Merriam-Webster Dictionary ${ }^{3}$ & $\begin{array}{l}\text { n. a native or inhabitant of Albania } \\
\text { adj. - }\end{array}$ \\
\hline Cambridge Learner's Dictionary ${ }^{4}$ & $\begin{array}{l}\text { n. a person from Albania; } \\
\text { adj. belonging to or relating to Albania, its people, or } \\
\text { its language }\end{array}$ \\
\hline $\begin{array}{l}\text { Longman Dictionary of Con- } \\
\text { temporary English }\end{array}$ & $\begin{array}{l}\text { n. someone who comes from Albania } \\
\text { adj. - }\end{array}$ \\
\hline $\begin{array}{l}\text { Oxford Advanced Learner's } \\
\text { Dictionary }\end{array}$ & $\begin{array}{l}\text { n. (a person) from Albania } \\
\text { adj. - }\end{array}$ \\
\hline $\begin{array}{l}\text { Online English Dictionary } \\
\text { from Macmillan Education }{ }^{7}\end{array}$ & $\begin{array}{l}\text { n. someone from Albania } \\
\text { adj. relating to Albania, or its language or culture }\end{array}$ \\
\hline $\begin{array}{l}\text { Collins Advanced English Dic- } \\
\text { tionary }^{8}\end{array}$ & $\begin{array}{l}\text { n. An Albanian is a person who comes from Albania. } \\
\text { adj. belonging or relating to Albania, its people, lan- } \\
\text { guage, or culture }\end{array}$ \\
\hline $\begin{array}{l}\text { Dictionary.com }{ }^{9} \text { based on The } \\
\text { Random House Unabridged Dic- } \\
\text { tionary }\end{array}$ & $\begin{array}{l}\text { n. a native or inhabitant of Albania or Albany, N.Y. } \\
\text { adj. pertaining to Albania, its inhabitants, or their lan- } \\
\text { guage }\end{array}$ \\
\hline $\begin{array}{l}\text { The Free Dictionary (English) }{ }^{10} \\
\text { based on The American Heri- } \\
\text { tage Dictionary of the English } \\
\text { Language, 5th Ed. }\end{array}$ & $\begin{array}{l}\text { n. a. A native or inhabitant of Albania. } \\
\text { b. A person of Albanian ancestry. } \\
\text { adj. of or relating to Albania or its people, language, } \\
\text { or culture }\end{array}$ \\
\hline $\begin{array}{l}\text { The Free Dictionary (German) } \\
\text { based on Collins German Dic- } \\
\text { tionary - Complete and } \\
\text { Unabridged } 7 \text { th Ed. }\end{array}$ & $\begin{array}{l}\text { n. someone with the citizenship of Albania } \\
\text { adj. relating to Albania }\end{array}$ \\
\hline Duden Wörterbuch (German) ${ }^{12}$ & $\begin{array}{l}\text { n. designation for an inhabitant of Albania } \\
\text { adj. concerning Albania, the Albanians; originating } \\
\text { from the Albanians, belonging to them }\end{array}$ \\
\hline $\begin{array}{l}\text { Digitales Wörterbuch der } \\
\text { deutschen Sprache }\end{array}$ & $\begin{array}{l}\text { n. an inhabitant of Albania; someone with Albanian } \\
\text { citizenship; someone who (originally) comes from } \\
\text { Albania } \\
\text { adj.- }\end{array}$ \\
\hline Dizionario Italiano ${ }^{14}$ & $\begin{array}{l}\text { n. native or inhabitant of Albania } \\
\text { adj. relating to Albania }\end{array}$ \\
\hline $\begin{array}{l}\text { Dizionario Italiano - Grandi } \\
\text { Dizionari }^{15}\end{array}$ & $\begin{array}{l}\text { n. a native, an inhabitant of Albania; a person } \\
\text { belonging to a minority speaking Albanian language } \\
\text { in central Italy, Serbia, Macedonia, Greece } \\
\text { adj. of Albania }\end{array}$ \\
\hline Treccani Vocabolario ${ }^{16}$ & $\begin{array}{l}\text { n. an inhabitant of Albania. The name is extended } \\
\text { also to the inhabitants of the Albanian colonies in } \\
\text { Turkey, Greece, Dalmatia, and, in particular, those } \\
\text { created by immigration in various regions of central } \\
\text { Italy and Sicily. } \\
\text { adj. of the Republic of Albania }\end{array}$ \\
\hline
\end{tabular}




\begin{tabular}{|l|l|}
\hline Dizionario Internazionale $^{17}$ & $\begin{array}{l}\text { Albanese - n. a native or an inhabitant of Albania } \\
\text { adj. of Albania }\end{array}$ \\
\hline $\begin{array}{l}\text { Hrvatski jezični portal }{ }^{18} \\
\text { (Croatian) }\end{array}$ & $\begin{array}{l}\text { n. } 1 \text {. a native or person holding citizenship of Albania; } \\
\text { 2. a person that is Albanian by nationality. } \\
\text { "Arbanas, Arnaut, Šiptar, Gegi" are listed as synonyms. } \\
\text { adj. 1. relating to Albania or Albanians } \\
\text { 2. undeveloped, obsolete }\end{array}$ \\
\hline Online rečnik ${ }^{19}$ (Serbian) & $\begin{array}{l}\text { n. an inhabitant of Albania. } \\
\text { "Arnaut, Šcipetar, Šiptar" are listed as synonyms. } \\
\text { adj. - }\end{array}$ \\
\hline Fjalor Shqip ${ }^{20}$ (Albanian) & $\begin{array}{l}\text { n. an indigenous resident of Albania or one of Alba- } \\
\text { nian origin; a member of the Albanian nation } \\
\text { adj. - }\end{array}$ \\
\hline $\begin{array}{l}\text { Fjalor i Gjuhës Shqipe }{ }^{21} \\
\text { (Albanian) }\end{array}$ & $\begin{array}{l}\text { n. a local resident of ethnic Albania or of ethnic Alba- } \\
\text { nian origin; a member of the Albanian nation } \\
\text { adj. - }\end{array}$ \\
\hline
\end{tabular}

Table 1: Definition of the ethnic term Albanian in various monolingual online dictionaries

As can be seen, most of the dictionaries defined the noun using geographical criteria, defining the ethnicity term as "an inhabitant/a native of a COUNTRY", "someone from a COUNTRY". As pointed out by Rader (1989), such a designation may be problematic as there could be large communities living outside the borders of the country with whose name their ethnonym is related. We are purposefully not using the term their "homeland", as these could be autochthonous communities of people who do not hail from such a country but have always lived elsewhere. In this particular case, autochthonous communities of Albanians live in a number of countries outside Albania (Montenegro included). Also, there are large Albanian immigrant communities in many Western European and North American countries. In fact, more ethnic Albanians live outside Albania than inside it, which makes this kind of a definition even more problematic.

Some dictionaries reduced the definition of the noun to just citizenship ("someone with the citizenship of a COUNTRY"). We also find this very problematic as citizenship may be held by members of ethnic minorities living in that particular country who do not belong under the related ethnic term, e.g. in this particular case, there are Serbs, Montenegrins and Greeks living in Albania, many of them probably holding the Albanian citizenship but, generally, they would not call themselves Albanians. Equating citizenship with how one identifies himself/herself may be the prevailing norm in some countries, but in the Balkans, for instance, this has never been the case. On the other hand, the definition is also problematic as there are many ethnic Albanians living, for instance, in Montenegro and having a Montenegrin citizenship, but some of 
them would not identify themselves as Montenegrins.

As noted in the literature, complex issues are simplified in dictionaries and sometimes this is more justified if a dictionary is intended for an international audience, who just needs a general idea of what an ethnicity term that they are not familiar with stands for (Murphy 1998). Still, we must point out that even some international dictionaries did offer more apposite definitions when it came to the adjectival forms of the term, involving the issue of "culture" and including additionally the wording "relating to" in their definition, e.g. "belonging or relating to a COUNTRY, its people, language, or culture" (Collins Advanced English Dictionary) or "of or relating to a COUNTRY or its people, language, or culture" (The Free Dictionary based on The American Heritage Dictionary of the English Language). Namely, "belonging" and "pertaining" are too exclusive to accommodate for some of the cases discussed above (e.g. autochthonous communities of Albanians living outside Albania). "Relating to" is broader and more inclusive than these two forms, given that the ethnic communities living outside the country from whose name their ethnonym was derived, are always "related to" it in certain ways (culturally, language-wise, etc.). Going beyond geography to include culture (as well as the relation to the language), as typically one of the defining characteristics of an ethnicity, certainly is a step forward in defining ethnicity terms.

Some dictionaries from countries with large communities of Albanians offered more detailed descriptions. One such country is Italy, in which there are substantial Albanian immigrant communities. Of the four Italian dictionaries included in this review (these are all the online monolingual dictionaries for this language which we were able to find via Google search), two are quite simply based on geography, in the ways discussed above, and the other two invest more efforts in defining this community and use particularised definitions for this ethnicity. In Dizionario Italiano - Grandi Dizionari, this ethnicity also includes Albanian minorities living in several countries, who are thus defined through their language ("a minority speaking the Albanian language"), as well as geographically ("in central Italy, Serbia, Macedonia, Greece"), though this list of countries could also be contested by some as being too narrow. The Treccani Vocabolario includes immigrant communities in certain countries and regions, as well as colonies in three territories, but fails to include some significant autochthonous communities outside Albania (for instance, in Montenegro and North Macedonia). What is evident is that the lexicographers had in mind that the members of all these communities might be using their dictionary and a particularised definition would be more suitable in this case. Even though the said definitions could both be said to be lacking in some respects, this customised approach in defining an ethnicity whose members are amongst the dictionary's target audience is commendable in our opinion.

Croatia is a Balkan country with a small Albanian minority. The Croatian dictionary (Hrvatski jezični portal) defines this ethnic term in terms of geography and citizenship ("a native or person holding citizenship of Albania") and also as 
follows: "a person that is Albanian by nationality", which could be characterised as a circular definition. While a circular definition solves the problem of political correctness and inclusivity, it certainly is not precise enough from a lexicographic point of view. This dictionary entry also lists some other names for this ethnicity as synonyms, one of which Albanians now find politically incorrect or even offensive ("Šiptar"), with no label which would mark it as such.

The same is the case with another regional dictionary, a Serbian one (Online rečnik). Serbia has a substantial Albanian minority and one of its regions, Kosovo, inhabited mostly by Albanians, declared its independence (after a history of ethnic conflicts in the region), now recognised by a considerable part of the international community. This dictionary defines an Albanian in the simplest terms, as "an inhabitant of Albania", and lists the same term ("Šiptar") as a synonym without a label which would warn that this is a politically incorrect or disparaging term. We find that not using labels to mark this ethnic term as offensive is not a good practice, especially bearing in mind that these are regional and local dictionaries, the target users of which include these minorities.

We also examined two Albanian online dictionaries. They both added the meaning of "a member of the Albanian nation", similarly to the second meaning in the Croatian entry, which, despite being inclusive, we commented on as being a circular definition.

In summary, most dictionaries used rudimentary definitions for ethnicities and in the literature we saw that this is recommended, at least to a certain level (Rader 1989; Murphy 1998). As suggested above, we cannot expect international dictionaries to have detailed definitions of all ethnicities, but we did see that some of them used more inclusive definitions, involving culture and the wording "relating to" (instead of exclusively "belonging to"), which we think could be an appropriate model for international dictionaries. Some dictionaries went beyond the standardised approach when treating a minority which is substantial in the region for which the dictionary is intended. This customised approach, although it was slightly flawed in some respects in the dictionaries we inspected, could be recommended for such cases, as it provides more inclusivity. In addition, if a certain ethnicity term could be seen as politically incorrect or offensive, then it is certainly advisable to label it as such. Failing to do this might lead to a backlash from some communities, which could be justified, at least to some degree. We will describe one such extreme case in the next section.

\section{Problematisation of ethnicity and ethnicity-related terms in a dictionary: A case study from Montenegro}

This section will focus on a case study from Montenegro. Namely, shortly after its publication, the first dictionary of the Montenegrin language provoked violent reactions and protests from some Albanian parties and the Bosniak Party, representing two ethnic minorities living in Montenegro, due to its treatment of 
certain ethnicity and ethnicity-related terms. The protests had an epilogue in the Parliament and eventually caused the publisher, the Montenegrin Association of Sciences and Arts (MASA), to revoke the dictionary.

The first volume of Rječnik crnogorskog književnog i narodnog jezika (English translation: Montenegrin Dictionary of Vernacular and Literary Language), which contained 12,018 words beginning with the letters A, B and V, was published in March 2016, as the most important project of Montenegrin lexicography, representing the first complete overview of the lexical complexity of the Montenegrin language and laying the foundations for the development of the dictionaries of this type in Montenegro. As stated in the Preface, p. XI, the dictionary itself, being general and descriptive, should reflect social, scientific and civilisational reality, and give the first complete presentation of the lexical structures of the Montenegrin language, of its functional and stylistic diversity; in addition to providing a linguistic contribution, it was also supposed to be of a great cultural and national identity significance.

Soon after its publication, the problem with the definitions of the term Albanac (Eng. translation: Albanian) and its derived forms albanizacija (Eng. trans.: Albanisation) and albanizovati (Eng. trans.: to albanisate), which were seen as offensive and wrong by the Albanian people living in Montenegro, grew into a big political issue and it was regarded as case of "culturocide". A group of intellectuals, linguists, political activists and representatives of different state and private institutions, including the Albanian and the Bosniak people living in Montenegro, harshly criticised the management of MASA and the authorial team of the dictionary. They argued that MASA did not have a very favourable opinion of co-life and multiculturalism in Montenegro, and that MASA had the agenda to define, shape, recommend, propagate and try to spread their own desires, frustrations, prejudices, stereotypes, fears, covert and overt hatred. An MP of Albanian ethnicity in protest even tore a few pages of the dictionary during a live session of the National Assembly. The specific problems raised are described below:

1. Firstly, a problem arose with the ethnic term Albanac (Eng. translation: Albanian), which is defined in this dictionary as "an inhabitant of Albania; someone who is originally from Albania" (p. 43) ${ }^{22}$. This definition was seen as too reductionist, given that a substantial autochthonous Albanian minority lives in Montenegro. It follows from the dictionary definition that every Albanian must be originally from Albania and that (s)he cannot be an autochthonous inhabitant of another country and be originally from it. The dictionary definition, the Albanian representatives argued, denied them their autochthonicity in Montenegro. The authorial team argued that this was a rudimentary definition, applied to every ethnic entry in the dictionary, but this did not appease the Albanian representatives, who accused MASA of having a hidden agenda of not representing them as autochthonous in Montenegro.

Therefore, applying the standardised approach (which was followed by 
many international dictionaries, as we saw in Section 3), in this particular case was problematic, given the ethnic sensitivities in the country, some of them surrounding the issue of ethnic autochthonicity.

2. Another problem arose with the ethnicity-related terms albanizacija (Eng. trans.: Albanisation) and albanizovati (Eng. trans.: to albanisate), which were defined as "imposed" assimilation processes, implying aggressive actions, the critics argued. They argued that some other assimilation terms in this dictionary, did not suggest imposition - for instance, the critics referred to how balkanizacija (Eng. transl.: Balkanisation) and amerikanizacija (Eng. transl.: Americanisation) were defined in MASA's dictionary:

- Balkanisation: "adoption of the characteristics of the languages and cultures of the Balkan peoples, adoption of the Balkan tradition" (p. 130);

- Americanisation: "1. to give someone or to something the features of the American way of life and culture; 2. to receive American characteristics, way of life and thinking, to become similar to the Americans" (pp. 56-57).

In contrast, this is how albanizacija (Eng. trans.: Albanisation) was defined:

- Albanisation: "1. to convert to Albanians; to impose the Albanian language, culture and customs on other peoples; 2. to became an Albanian; to get the characteristics of an Albanian" (p. 43).

As can be seen, the definition of the noun balkanizacija (Eng. transl.: Balkanisation) does not mention or imply any coercion, any imposition or any kind of oppression by either neighbouring or distant peoples. Moreover, balkanisation as here described happens naturally like acquiring a language. Similarly, amerikanizacija (Eng. transl.: Americanisation) indicates the introduction, acceptance, or receiving some of American characteristics, which seems to be carried out voluntarily by both those who provide the characteristics and those who accept them. Contrary to that, this dictionary suggests that Albanians imposed their culture, language and customs, and converted other nations into Albanians through the albanisation process. This was also reinforced in the example accompanying the entry, which also confirms the "imposition" implied in the definition:

Asking himself, he also offered some answers - based on the experiences of Orthodox refugees from Albania who were exposed to systematic albanianisation, especially in the time after World War II war in 1945. (Zoran Lakić)

Semantically analysed, all these terms (Albanisation, Americanisation and Balkanisation) have the same semantic base resting on assimilation (linguistic, cultural or national), which MASA lexicographers defined without implying imposition (p. 93), as "the adjustment of the minority to the majority adopting the characteristics of the majority". However, they did not use this definition as 
their standard for all assimilation processes, but defined them in a customised way, depending on the ethnicities involved. In this particular case, the lexicographers did not opt for a standardised approach when treating assimilation as an ethnicity-related term, which created problems.

In defining albanizacija (Eng. trans.: Albanisation), the MASA lexicographers were guided by their corpus, in which they opted to include various texts from the last 200 years. However, this means that the whole of the 19th century and the early 20th century were included, which are periods marked by a series of ethnic wars and political ideologies imbued with inter-ethnic hatred and intolerance, which the present-day society has been trying to overcome for decades now (to varying success). So, the problem with these ethnicity-related terms might be found in the corpus itself - as Wierzbicka argues (1995: 194), obsolete corpora do not reflect the contemporary reality. The lexicographers did not use labels to mark potentially disparaging meanings of the term or its use in a historical context.

3. Another problematised ethnicity term in the dictionary was "Agarjanin" (Eng. trans.: "Hagarian"23), defined as: "muslim, Turk; unbeliever, infidel" (p. 10) and accompanied by a corpus example illustrating the second meaning. The Bosniaks were especially critical of this definition as it implied an equation sign between Muslims, Turks, and infidels, they argued. The senses of the word were delimited with a comma and a semi-colon; numbers were not used to imply different meanings. No disparaging labels were used or notes on the term's historic use and meanings.

This particular case points to the importance of delimiting different meanings and marking those that are disparaging. This remains the issue, however, of what qualifies as "disparaging", as we have seen, different tendencies in the literature regarding such markings. In this case, however, a label marking the offensive uses and probably some note on the historical context of the word would have been needed.

The pressure from the Albanian and the Bosniak communities was such that the whole dictionary was revoked over a few definitions. As we have seen, in one case the problem was following a standardised definition of all ethnicity terms equally, which did not account for the autochthonous communities living outside the country from whose name their ethnonym was derived. In the second case, the lexicographers did not use a standardised approach to define assimilation processes relating to certain ethnicities, governed by their corpus which did not reflect a modern reality. In the third case, no disparaging labels were used to mark the offensive uses of the term, nor were there any delimitations between the non-offensive and the offensive meanings.

Following the outcry and criticism, the Parliament adopted a Resolution on the dictionary with recommendations to MASA to stop its distribution, which MASA did. A new, revised edition was to be issued, but this has not happened in the five years since the event. Perhaps such definitions would not 
have caused an outcry in another country or, at least, the reaction would not have been equally harsh, but in a country like Montenegro, in which the issue of ethnicity is an extremely sensitive one, along with the issue of autochtonicity and religion (the lines along which many stark divisions are drawn in the society), these issues become a matter to which a lexicographer should devote maximum attention.

\section{Conclusions}

In this paper we described the problems of defining ethnicity terms in dictionaries. We reviewed a number on online monolingual dictionaries and critically analysed their ethnic definitions, and we also described the case of Rječnik crnogorskog knjižeonog i narodnog jezika (Eng. trans.: Montenegrin Dictionary of Vernacular and Literary Language), which was revoked over a few ethnicity and ethnicity-related terms.

We found that most of the ethnic definitions in dictionaries are rather simple, being typically geographically or citizenship-based, but some of the definitions also proved more inclusive - such was the case with the definitions involving culture, as well as with the adjectival forms which included the wording "relating to". Such definitions offered good models for international and learner's dictionaries. We also commented on the pros and cons of the customised approach to some ethnicity terms used in a small number of the dictionaries we examined. Having analysed the case of a few ethnicity and ethnicity-related terms in a Montenegrin dictionary and the public reaction which followed its publication, we concluded the same thing as Hauptfleisch (1993) and Burchfield (1980): editors and lexicographers should be very cautious in how they define and label ethnicity and ethnicity-related terms. As we have seen, sometimes rudimentary definitions will not suffice, while at other times lack of standardisation will create problems.

As suggested in the literature (Rader 1989; Murphy 1998), we argue that some level of standardisation of ethnicity definitions in dictionaries should certainly be established, but we also commend a partly customised approach when defining ethnicities which are amongst the target audience of a dictionary, particularly if the issue of ethnicity is a sensitive one in a particular society. It is the responsibility of lexicographers to examine more carefully the characteristics of such ethnic groups, their autochtonicity, culture and religion, to accompany the definitions related to ethnicity with non-ideologically imbued examples, and to mandatorily use appropriate labelling to mark the disparaging ethnicity terms and uses.

\section{Endnotes}

1. https://ictionary.cambridge.org/dictionary/english/research

2. This section is not retained in Landau (2001). 
3. https://www.merriam-webster.com/dictionary/Albanian

4. https://dictionary.cambridge.org/dictionary/english/albanian

5. https://www.ldoceonline.com/dictionary/albanian

6. https://www.oxfordlearnersdictionaries.com/definition/english/albanian?q=albanian

7. https://www.macmillandictionary.com/dictionary/british/albanian_1

8. https://www.collinsdictionary.com/dictionary/english/albanian

9. https://www.dictionary.com/browse/albanian?s=t

10. https://www.thefreedictionary.com/albanian

11. https://de.thefreedictionary.com/albaner

12 https://www.duden.de/rechtschreibung/Albaner

13. https://www.dwds.de/wb/Albaner

14. https://www.dizionario-italiano.it/dizionario-italiano.php?parola=albanese

15. https://www.grandidizionari.it/Dizionario_Italiano/parola/A/albanese.aspx?query=albanese

16. http://www.treccani.it/vocabolario/ricerca/albanese/

17. https://dizionario.internazionale.it/parola/albanese

18. http:/hjp.znanje.hr/index.php?show=search

19. https://onlinerecnik.com/leksikon/srpski/albanac

20. http://www.fjalorshqip.com

21. https://fjalorthi.com/shqiptar

22. The definitions from the Dictionary given here were literally translated into English.

23. Descendants from Abraham's son Ishmael, whose mother was Hagar.

\section{References}

\section{Online dictionaries}

Cambridge Learner's Dictionary. 2020. https://dictionary.cambridge.org

Collins Advanced English Dictionary. 2020. https://www.collinsdictionary.com/

Dictionary.com. The Random House Unabridged Dictionary 2020. https:/www.dictionary.com

Digitales Wörterbuch der deutschen Sprache. 2020. https://www.dwds.de

Dizionario Internazionale. 2020. https://dizionario.internazionale.it/

Dizionario Italiano - Grandi Dizionari. 2020. https:/www.grandidizionari.it/Dizionario_Italiano

Dizionario Italiano. 2020. https://www.dizionario-italiano.it/

Duden Wörterbuch. 2020. https://www.duden.de

Fjalor i Gjuhës Shqipe. 2020. https://fjalorthi.com

Fjalor Shqip. 2020. http:/www.fjalorshqip.com

Hrvatski jezični portal. 2020. http:/hjp.znanje.hr/

Longman Dictionary of Contemporary English. 2020. https://www.ldoceonline.com

Merriam-Webster.com. 2020. https://www.merriam-webster.com

Online English Dictionary from Macmillan Education. 2020. https://www.macmillandictionary.com

Online rečnik. 2020. https://onlinerecnik.com/leksikon

Oxford Advanced Learner's Dictionary. 2020. https://www.oxfordlearnersdictionaries.com

The Free Dictionary - The American Heritage Dictionary of the English Language. Fifth Edition. 2020.

https://www.thefreedictionary.com 
The Free Dictionary - Collins German Dictionary. Complete and Unabridged Seventh Edition. 2020. https://de.thefreedictionary.com

Treccani Vocabolario. 2020. http://www.treccani.it/vocabolario/

\section{Other literature}

Barnickel, K.-D. 1999. Political Correctness in Learners' Dictionaries. Herbst, T. and K. Popp (Eds.). 1999. The Perfect Learners' Dictionary(?): 161-174. Tübingen: Niemeyer.

Brass, P.R. 1991. Ethnicity and Nationalism: Theory and Comparison. Newbury Park, CA: Sage.

Burchfield, R. 1980. Dictionaries and Ethnic Sensibilities. Michaels, L. and C. Ricks (Eds.). 1980. The State of the Language: 15-23. Berkeley: University of California Press.

Busse, U. 2000. Recent English Learners' Dictionaries and Their Treatment of Political Correctness. Mogensen, J.E., V.H. Pedersen and A. Zettersten (Eds.). 2000. Symposium on Lexicography IX. Proceedings of the Ninth International Symposium on Lexicography, April 23-25, 1998 at the University of Copenhagen: 165-201. Tübingen: Niemeyer.

Chandra, K. 2006. What is Ethnic Identity and Does It Matter? Annual Review of Political Science 9: 397-424.

Connor, W. 1984. Eco- or Ethno-nationalism? Ethnic and Racial Studies 7(3): 342-359.

Dieckmann, W. 1975. Sprache in der Politik. Einführung in die Pragmatik und Semantik der politischen Sprache. Mit einem Literaturbericht zur 2. Auflage. Heidelberg: Carl Winter.

Ezquerra, M.A. 1995. Political Considerations on Spanish Dictionaries. Kachru, B.B. and H. Kahane (Eds.). 1995. Cultures, Ideologies, and the Dictionary: Studies in Honor of Ladislav Zgusta: 143-152. Tübingen: Niemeyer.

Francis, E.K. 1947. The Nature of the Ethnic Group. American Journal of Sociology 52(3): 393-400.

Gabbert, W. 2006. Concepts of Ethnicity. Latin American and Caribbean Ethnic Studies 1(1): 85-103.

Hauptfleisch, D.C. 1993. Racist Language in Society and in Dictionaries: A Pragmatic Perspective. Lexikos 3: 83-139.

Horowitz, D.L. 1985. Ethnic Groups in Conflict. Berkeley: University of California Press.

Kalogjera, D. 2001. "Teške riječi" za leksikografa. Filologija 36-37: 263-271.

Landau, S. 1984. Dictionaries. The Art and Craft of Lexicography. New York: The Scribner Press.

Landau, S. 2001. Dictionaries. The Art and Craft of Lexicography. Second edition. Cambridge: Cambridge University Press.

Montenegrin Association of Sciences and Arts. 2016. Rječnik crnogorskog književnog i narodnog jezika (Montenegrin Dictionary of Vernacular and Literary Language). Podgorica: Montenegrin Association of Sciences and Arts. (revoked)

Moon, R. 1989. Objective or Objectionable: Ideological Aspects of Dictionaries. Knowles, M. and K. Malmkjær (Eds.). 1989. ELR Journal 3: 59-95.

Murphy, M.L. 1991. Defining Racial Labels: Problems and Promise in American Dictionaries. Dictionaries: Journal of the Dictionary Society of North America 13(1): 43-64.

Murphy, M.L. 1998. Defining People: Race and Ethnicity in South African English Dictionaries. International Journal of Lexicography 11(1): 1-33.

Nissinen, S. 2015. Insulting Nationality Words in Some British and American Dictionaries and in the BNC. MA thesis. Tampere: University of Tampere. 
Norri, J. 2000. Labelling of Derogatory Words in Some British and American Dictionaries. International Journal of Lexicography 13(2): 71-106.

Rader, J. 1989. People and Language Names in Anglo-American Dictionaries. Dictionaries. Journal of the Dictionary Society of North America 11: 125-138.

Rothschild, J. 1981. Ethnopolitics: A Conceptual Framework. New York: Columbia University Press.

Schutz, R. 2002. Indirect Offensive Language in Dictionaries. Braasch, A. and C. Povlsen (Eds.). 2002. Proceedings of the Tenth EURALEX International Congress, EURALEX 2002, Copenhagen, Denmark, August 13-17, 2002: 637-641. Copenhagen: Center for Sprogteknologi, Copenhagen University.

Ştefănescu, M. 2015. Dysphemisms for Ethnicity: Cautionary Labelling of Disparaging Ethnic Words in Some Romanian Dictionaries. Studia Universitatis Babeş-Bolyai - Philologia 60(2): 51-63.

Veisbergs, A. 2002. Defining Political Terms in Lexicography: Recent Past and Present. Braasch, A. and C. Povlsen (Eds.). 2002. Proceedings of the Tenth EURALEX International Congress, EURALEX 2002, Copenhagen, Denmark, August 13-17, 2002: 657-667. Copenhagen: Center for Sprogteknologi, Copenhagen University.

Wachal, R.S. 2002. Taboo or Not Taboo: That is the Question. American Speech 77(2): 195-206.

Wierzbicka, A. 1995. Dictionaries and Ideologies: Three Examples from Eastern Europe. Kachru, B.B. and H. Kahane (Eds.). 1995. Cultures, Ideologies, and the Dictionary: Studies in Honor of Ladislav Zgusta: 181-196. Tübingen: Niemeyer.

Xu, Jieshun. 2002. Ethnic Group and Nationality: The Concepts and Their Relationships. Ethnonational Studies 1: 12-18. 